\title{
WOMEN'S ROLES AND CONFLICTS IN DIVAKARUNI'S ARRANGED MARRIAGE
}

\author{
Zakiyatul Mufidah $^{1, *}$, Miftahur Roifah ${ }^{2}$ \\ ${ }^{1}$ English Study Program, Faculty of Social and Cultural Science, Universitas Trunojoyo Madura, Jl. Raya \\ Telang PO BOX 2 Kamal Bangkalan, Indonesia \\ ${ }^{2}$ English Study Program, Faculty of Social and Cultural Science, Universitas Trunojoyo Madura, Jl. Raya \\ Telang PO BOX 2 Kamal Bangkalan, Indonesia
}

\section{ARTICLE INFO}

Keywords:

Feminism

Marriage

Women's conflict

Women's role

Article History:

Received: 17/11/2019

Accepted: 19/05/2020

Available Online:

31/05/2020

\begin{abstract}
The cases of women experiencing gender-biased, injustice, abuse, and violence do not only exist in stories of literary works but it does exist in real life as we believe that literary text is the reflection of the real life. In addition, feminism is more likely concerning the division of gender roles and its implication to the women's life to be academically worth it. This study is intended to identify what kind of women's roles and conflicts are portrayed in literary works and to explain how women's roles and conflicts are reflected through literary text. This study is a qualitative study which applies close reading in finding the data. The results of the study show that the roles of women in Divarakuni's Arranged Marriage are mainly aiming at fulfilling the domestic affairs. While, two conflicts are faced by the women; domestic violence and psychological pressures by their husbands and family. In addition, it also indicates that most women are still prevalent to destiny as housewives and to serve their husband's needs.
\end{abstract}

2442-305X / (C) 2020 The Authors, this is open access article under the (CC-BY-NC) license (https://creativecommons.org/licenses/by-nc/4.0/), DOI: 10.19105/ojbs.v14i1.2733

\footnotetext{
$\overline{\text { * Corresponding Author: }}$

Email address: zakiyatul.mufidah@trunojoyo.ac.id (Z. Mufidah)
}

\section{A. Introduction}

The discussion and dispute about women have always been interesting as it bears unfinished issues related to women's right, freedom, struggle, and how they live their life in such uneasy world. Women's matters are always rising in any element of social life. A woman which according to Beauvoir, becomes the entity who is constructed as the second class has been able to contribute to the academic and scientific field during history. ${ }^{1}$ Hence, it is never indifference to discourse women in today's context. The changing dynamic of women's role and position within society has begun since the modernism era. The feminism waves which emerged during the 19 century seemed successful in campaigning

\footnotetext{
1 Simone de Beauvoir, The Second Sex, vol. II (London: Jonathan Cape Thirty Bedford Square, 1956), 8.
} 
women's issues on gender injustice, gender stereotypes, and other issues that disabled women from an equal position with men. The cases of women experiencing gender-biased, injustice, abuse, and violence do not only exist in stories of literary works but it does exist in real life as we believe that literary text is the reflection of the real life. In addition, feminism is more likely concerned with the division of gender roles and its implication to the women's life to be academically worth it.

Myriad sources and stories are recording the role of women along with their life dynamics to be a central issue under the feminism theory. The emerge of this theory actually elucidates women's life, role, and conflict as either by nature or culture. Besides, women in many cases are still vulnerable to being oppressed and marginalized. Often, because of gender categorization, women are generally categorized as an inferior group who are supposed to be the subordination of men. However, feminism is more likely concerned with the division of gender roles and its implication to the women's life to be academically worth it. It is feminism that has placed gender in the academic agenda. $^{2}$ One of feminism critical reading do is to question whether the literary text promotes gender equality and pay attention to how women are constructed within the text. Besides, feminism would examine whether the gender role and gender injustice are already systemic as it is produced by the

\footnotetext{
${ }^{2}$ John Storey, Cultural Analysis and Pop Culture (London: Pearson, 2009), 151.
}

social system. When the word "system" is perceived as interpersonal networks who are socially empowered, it might lead to the changes in the social system in a society. ${ }^{3}$

In the light of feminism theory, there are a lot of literary works that can be read and analyzed more sensitively, deeply and comprehensively for it tries to scrutinize any element in the literary works which has tendency about women's conflict, oppression and how such issues are addressed within the literary works. Further, the core of feminism is the belief that women are subordinated to men in society. Hence, it seeks to liberate women from this subordination and to reconstruct society in such a way that patriarchy is eliminated. It is believed that the feminism movement postulates that the domination of one human being by another is the basic evil in society. Dominance in human relationships is the target of their opposition. 4

Short story is one of literary works that is not only popular but it can also be categorized as a must-have thing for those who love reading literary works. Moreover, novel is also a sort of medium for the writers to express their emotions and thoughts, and ideas. It becomes an effective vehicle to deliver certain messages to the readers. Once the readers get involved in the literary readings, it is more likely to be influenced by what it is in the literary text. In addition,

\footnotetext{
3 Holly Lewis, The Politics of Everybody (London: Zedbooks, 2016), 21.

${ }^{4}$ Bell Hooks, Feminism Theory from Margin to Center (London: Routledge, 2015), 84.
} 
short story is a fiction which is somehow people sees it as a trivial thing, yet, it has a magnificent power to reflect, represent or even persuade the readers about social life and how they see the world.

Living in a world of patriarchy where men's power is considered as everything has disabled women from a feel free situation. ${ }^{5}$ The ideology of patriarchy also worsens women's life at some points. Women, in most cases even accept such construction as something innate and natural. $^{6}$ Many problems and hard situations are most likely experienced by women because they have no choice and caused by the men around them. The closest persons usually become a potential repercussion in which women should come up with.

Arranged Marriage is a compilation of short stories by Indian woman writer Chitra Barnajee Divakaruni. The short stories describe how women in India who migrated to the USA have abundant conflicts due to their roles and position as women. They are living in such modern life and place, yet, they are still tied strongly by the traditional values and culture from which they originally come. Conflicts faced by women are various, ranging from internal to the external conflicts which ultimately leave the main characters (women) live desperately the rest of their life. Therefore, this research aims to identify what kind of women's roles and conflicts reflected in the short stories and how women's roles and

\footnotetext{
${ }^{5}$ Storey, Cultural Analysis and Pop Culture, 96.

6 Lois Tyson, Critical Theory Today (New York: Garlang Publishing, 1996), 43.
}

conflicts are portrayed within the short stories.

The data of this research is a novel written by Chitra Banerjee Divakaruni entitled Arranged Marriage. Some scholars have studied this novel from various perspectives. Among them are as follows: first is Realism in Chitra Banerjee Divakaruni's Arranged Marriage written by Jasmine Fernandez. ${ }^{7}$ The study talks about the background of Divakaruni that influence the content of the stories. Divakaruni brings many issues of Diaspora women who live in America. She is also part of the Diaspora, so she gives a realistic perspective about the condition and the life of women in America. Second is the study written by Dr. K. Lalitha Bai. ${ }^{8}$ Her study explores the identity construction of Diaspora women who live in America. She also focuses on the class difference of Indian women who live in America that they have to face. Women in India live in class difference and even they have moved from their country they still cannot free from that struggle. The third is a study from Rositta Joseph Valiyamattam. $^{9}$ The title of her study is Diaspora and Feminism in Chitra Banerjee Divakaruni's Arranged Marriage.

\footnotetext{
7 Jasmine Fernandez, "Realism in Chitra Banerjee Divakaruni's Arranged Marriage," IOSR Journal of Humanities and Social Science 19, no. 3 (2014): 99-101, https://doi.org/10.9790/0837-193299101.

${ }^{8}$ K. Lalitha Bai, "Divakaruni's Arranged Marriage: Quest for a New Beginning," International Journal of Humanities and Social Science Invention 6, no. 11 (November 2017): 83-86.

9 Rositta Joseph Valiyamattam, "Diaspora and Feminism in Chitra Banerjee Divakaruni's Arranged Marriage," LITERARIA: An International Journal of New Literature Across the World - Special Issue on Indian Diaspora 3, no. 1 (June 2013): 24-40.
} 
She focuses her study in the discussion of feminine identity that an Indian woman is trying to achieve by moving to another country. This research is using the same data with above-mentioned studies; however, this research has a different focused area. This research tries to reveal what kind of roles and conflicts faced by women who have a strong traditional and cultural family background. Besides, this research also exploring women's roles and conflicts which are portrayed through the compilation of short stories by Divakaruni in Arranged Marriage.

\section{B. Method}

The method of this study is qualitative as it deals with texts in explaining and interpreting the data. ${ }^{10}$ In analyzing women's roles and conflicts, this study explores short stories collection, Arranged Marriage, written by Divakaruni Chitra Banerjee. There are 11 short stories included; The Bats, Clothes, Silver Pavements - Golden Roofs, The Word Love, A Perfect Live, The Maid Servant's Story, The Disappearance, Doors, The Ultrasound, Affair, and Meeting Mrinal.

The book is taken as a source of data because Divakaruni presents women protagonist who experiences problems and struggles due to the division of gender roles in a patriarchal society. To support the analysis, the study used the theory of sex differences and gender roles in association with feminist criticism. The data is collected by reading the character's utterances and writer's

10 Uwe Flick, Designing Qualitative Research (London: SAGE Publications Ltd, 2007), 2. narration which involve the issues/ the discussion about women's gender roles and women's conflict. The data then are classified and picked based on some points of analysis to further being interpreted and analyzed with the theory provided. Some references are also used to assist in the analysis.

\section{Results}

\section{Women's Roles in Chitra Banerjee Divakaruni's Arranged Marriage}

Arranged Marriage is rich with the adventure of women from India in finding the possibility of change to make their life improved and more promising. The most dominant issue captured into the story is the narration about how those women live their life in different circumstances with multifaceted conflicts. Living in America, a place they don't grow up with, contests their cultural identity with reality. Struggle, dilemma, and depression are the major condition those women have to deal with. In spite of that, the women in Arranged Marriage are portrayed as strong and willing to change their situations in life, although sometimes they do also feel trapped in social demand. ${ }^{11}$ The social demands they are engaged with are not coming from the environment they live in, yet it is from their previous place which is still strongly knotted their belief and ideology.

Indian women are part of a place with abundant cultural wealth. India

\footnotetext{
11 Gunjan Agarwal and Gunjan Kapil, "Arranged Marriage: As an Example of Marginalized Relationships," IOSR Journal of Humanities and Social Science 19, no. 10 (2014): 89-93, https://doi.org/10.9790/0837-191028993.
} 
belongs to a cultural oriented society where traditions and social values are still strongly held by its people. ${ }^{12}$ One of the prominent fundamental cultures which still affect all the aspects of life of its people is patriarchy. Patriarchal mindset of its people provides an equivalent place for men and women in society, creating gap and difference to their roles and responsibilities. This reality does not offer any negotiation, shifting, or even changing to the gender roles because this culture is tightly bounded with the nature of sexual difference. People with patriarchal mindset believe that men and women are naturally different so that they will embody different roles too. Men with their strong physical characteristics are believed to be the leader of the family, getting the responsibility to support the family's financial condition so they can work and spend most of their time outside the house. However, women's physical characteristics are considered weaker than men, soft, calm, and having more sensitive feeling so they are given the responsibility to nurture children, manage the household, and take care of the family.

The patriarchal mindset indeed gives a huge impact on certain areas of life such as in relationship and marriage. Both men and women as an individual have already unconsciously constructed to follow the rules of patriarchal culture. Having entered into adulthood phase,

12 Minal J Damor, "Portrayal of Women in Chitra Banerjee Divakaruni's Arranged Marriage," International Journal of Research in All Subjects in Multi Languages 3, no. 6 (June 2015): 23-25. their demand to get into their gender roles is getting higher and constraining. They will be pushed to practice all responsibilities that belong to their gender role. A woman must do what she has to do and a man also must do what he has to do. This is the implication of patriarchal culture which the ideology has raised into social belief. However, women are insisted more than men in this circumstance under the claim that they are in the second position. ${ }^{13}$

Moreover, as a book talking about the journey of women, Arranged Marriage provides more facts and realities of Indian women's role both as a woman and as a wife. Arranged Marriage captures the life of Indian women before and after marriage, about the responsibilities they have to fulfill as a woman. "The stories of Divakaruni's novels feature Indian-born women torn between new and old-world values. Her stories give a laser-like insight into the feminine nature. Her skilled use of story, plot, and lyrical description gives the readers a many-layered look at her character and their respective worlds which are filled with fear, hope, and discovery. ${ }^{14}$ This book has several titles with different stories; The Bats, Clothes, Maid Servant, Ultrasound, Meeting Mirnal, Silver Pavement, A Perfect Life, Doors, and Affairs. One thing in common from all the titles from this book is the feeling of

\footnotetext{
13 Fernandez, "Realism in Chitra Banerjee Divakaruni's Arranged Marriage."

14 A Usha, "Immigrant Experience and SelfDiscovery of Women in the Select Novels of Chitra Banarjee Divakaruni: A Study," International Journal of English Research 3, no. 5 (September 2017): 11-13.
} 
the women in dealing with any problems which they try to show their strength, thoughtful mind, and acceptance. Overcoming conflict related to gender roles is not easy because they confront society and if they try to be different from what they are expected to, they have to carry on the social burden.

The first title in Arranged Marriage is The Bats. Divakaruni, the writer, points out the lives of women after marriage in this story. The woman narrated in this story is a wife and a mother who stuck up in a miserable marital life due to an abusive husband. Marriage is considered dislocates women both physically and emotionally, becoming institutions of passive suffering for women. When a woman entering into marriage, she must be ready to take off rights and freedoms as a single woman and transfers it under the power of her husband. Marriage is an institution of patriarchal culture in which the practice positions a husband as a leader, thus he has more power and privilege than a wife. In many cases, husbands usually misuse their power not to protect their wives but instead, they do violence to their wives. This reality is well captured by Divakaruni in The Bats:

"One morning when she was getting me ready for school, braiding my hair into the slick, tight pigtail that I disliked because it always hung stiffly down my back, I noticed something funny about her face. Not the dark circles under her eyes. Those were always there. It was high up on her cheek, a yellow blotch with its edges turning purple. It looked like my knee did after I bumped into the chipped mahogany dresser next to our bed last month."
"What's that, Ma? Does it hurt?" I reached up, wanting to touch it, but she jerked away."

"Nothing. It's nothing. Now hurry up or you'll miss the bus. And don't make so much noise, or you'll wake your father." 15

The woman in The Bats faces different situations which are ironic. A wife and a mother cannot neglect her roles and responsibilities to nurture his/her children although she has suffered physical violence from her husband. Patriarchal society believes that children are under the protection of a mother as their roles are in the region of domesticity. In India, marriage is a sacred institution and occupies a crucial role in Indian society. ${ }^{16}$ The typical Indian wife and mother will devote her life to her husband and children.

When they have to experience dissatisfaction in marriage, they will just go through it with any consequences they must bear with. The Indian society has no place for a woman, who walks out of the marriage because the marital bond to which she is bond. ${ }^{17}$ There is no coming back for a married woman as narrated in The Bats story, the woman chooses to endure the pain she gets from her husband and just perform her roles as a wife and a mother sincerely. In the same way, she doesn't feel at home even at her own home, but she attaches herself with her husband. She finds temporary solace by moving to her uncle's place but her

15 Chitra Banerjee Divakaruni, Arrange Marriage (New York: Anchor Books, 1995), 2.

${ }^{16}$ Agarwal and Kapil, "Arranged Marriage."

17 Fernandez, "Realism in Chitra Banerjee Divakaruni's Arranged Marriage." 99. 
mind wavers back to her husband. She writes to him as she is unable to listen to the words, which women often say "I wrote to him. I couldn't stand it, the stares and whispers of the women, down in the market place. The loneliness of being without him." 18

The miserable plight of women tortured by her husband is highlighted in this story. The value judgment of the world that is essentially male-oriented shows that if a woman is abandoned by her husband it is all but natural, but if the woman does the same, it is a sheer instance of profligacy. She dares not to live away from her husband for fear of public censure. Emancipation, selfanalysis, and self-evaluation never strike to her as she is unable to rise above the restrictions imposed by society. ${ }^{19}$

The roles of being a woman are not only connected with household duties as a wife or as a mother, however, a woman also has to carry out a task to serve her parents and her parents in law if they have been married. "A married woman belongs to her husband, her in-laws." ${ }^{20}$

It shows that the roles of women in a patriarchal society are very complex and demanding. In her second short story in Arranged Marriage, Divakaruni presents the realism of submissiveness a daughter must give to her parents and her parents in law. Clothes is a story of Sumita whom her marriage is arranged by her parents

\footnotetext{
18 Chitra Banerjee Divakaruni, Arrange Marriage (New York: Anchor Books, 1995), 11-12.

${ }^{19}$ Bai, "Divakaruni's Arranged Marriage: Quest for a New Beginning."

${ }^{20}$ Chitra Banerjee Divakaruni, Arrange Marriage (New York: Anchor Books, 1995), 19.
}

and as a daughter, she has to agree with her parents' choice. Grooms are selected by women's parents with dreams of settling down and living prosperously with the men chosen. ${ }^{21}$ In connection to that phenomenon, an Indian daughter have to approve her parent's choice and decision, due to the fact that in India, a girl is nurtured in such a way that she should stick to strong moral conduct and should never take independent decision regarding her own life and relationship. ${ }^{22}$

Arranged marriage in India is normal, as it becomes part of traditions. The idea of arranged marriage evokes images of loveless and choice-less union in which people, more often women, are enforced into marriage. Regardless of stereotype, arranged marriages in some form are still the norm in many if not most countries, including India which is often considered the vanguard of arranged marriages. $^{23}$

"For the first time it occurred to me that if things worked out the way everyone was hoping, l'd be going halfway around the world to live with a man I hadn't even met. Would I ever see my parents again? Don't send me so far away, I wanted to cry, but of course, I didn't. It would be ungrateful. Father had worked so hard to find this match

\footnotetext{
21 Brajesh Kumawat SGL and Payel Dutta Chowdhury, "The Discordant Marital Life of the Diaspora: A Study of Chitra Banerjee Divakaruni's Arranged Marriage and Manju Kapur's the Immigrant," Smart Moves Journal ljellh 3, no. 3 (May 17, 2017): 396-404.

22 Ritu Sharma, "Woman in Dilemma, A Critical Study of the Female Characters of Chitra Divakaruni's Arranged Marriage," International Journal of English and Literature 9, no. 1 (January 1, 2019): 17-24, https://doi.org/10.24247/ijelfeb20193.

${ }^{23}$ Agarwal and Kapil, "Arranged Marriage," 89-93.
} 
for me. Besides, wasn't it every woman's destiny, as Mother was always telling me, to leave the known for the unknown? She had done it, and her mother before her. A married woman belongs to her husband, her inlaws." 24

In the story of Clothes, Sumita acts as a good daughter for his parents, so she puts her trust in her parents' choice and decision. Through her action, Sumita is trying to complete her duty as a daughter and fulfill the expectation of patriarchal society by agreeing with her parents' choice. Accepting an arranged marriage is like gambling for a woman. They have no idea with whom they are married, so there will be two possibilities whether they are married to a good man or the bad one. In dealing with an arranged marriage, a girl firstly will be very excited, nervous, and probably her mind will full of romantic imagination.

In many cases, however, a girl's romantic imagination of a marriage is often damaged because the realities mostly give them disappointment and turn out to be in sharp contradiction to her expectation. ${ }^{25}$ The tradition of finding matches by matching the horoscopes of the boy and the girl sometimes miserable fails to assure domestic bliss to the beleaguered women, instead the domestic violence predominates. ${ }^{26}$

\footnotetext{
${ }^{24}$ Chitra Banerjee Divakaruni, Arrange Marriage (New York: Anchor Books, 1995), 18-19.

25 Jayasree Mukherjee, "Marred by Marriage: The Modern Indian Woman at the Crossroads in Chitra Banerjee Divakaruni's Arranged Marriage," Research Journal of English Language and Literature (RJELAL) 6, no. 1 (2018): 245-50.

26 B. Priya and A. Saburunnisa, "Immigrant Feminine Sensibility in Chitra Banerjee Divakaruni's
}

When a woman has already entered into a marriage institution, she must be willing to accompany her husband in whatever the circumstances are. Submissiveness is essential for a woman in marriage and she must give it to her husband. In the story entitled Silver Pavements, Golden Roofs, Pratima an Indian woman who is married to an Indian man and lives in America experiences hard times in her marital life. She must compromise with the condition of her husband whom he cannot well support his family's financial condition and often give her restriction in doing something.

"Your uncle does not like me to go out. $\mathrm{He}$ is telling me it is dangerous. "How can it be dangerous?" I say. It's just a ploy of his to keep her shut up in the house and under his control." ${ }^{27}$

Marriage is called a contract, an institution in which one party, the husband, has exercised the power of a slave-owner over his wife. ${ }^{28} \mathrm{~A}$ wife is like a husband's belonging which means that a husband gets privilege to rule and order his wife according to his will. In this case, a wife is expected to agree, accept, and does his husband's command without arguing. There is very little space for negotiation; a wife is not allowed to voice her thought even if she does not agree or feel inconvenience with the order. Therefore, marriage somehow gives unfair realities to a woman, because the division

Arranged Marriage," Think India 22, no. 2 (October 10, 2019): 156-59, https://doi.org/10.26643/thinkindia.v22i2.8683.

27 Chitra Banerjee Divakaruni, Arrange Marriage (New York: Anchor Books, 1995), 46.

${ }^{28}$ Agarwal and Kapil, "Arranged Marriage," 89-93. 
of roles between men and women in marriage are not balanced.

Moreover, the traditional roles of women in a patriarchal society are connected with motherhood. Even the motherhood that is a female prerogative is under the socio-cultural practices of patriarchy. ${ }^{29}$ Women in a patriarchal society are expected to get married, pregnant, having children, and take care of them. It is a great achievement for a woman if she can complete and maintain this role well. Otherwise, if a woman neglects to perform motherhood in her life, she will get negative stigma from her society. Two titles in Arranged Marriage, The Word Love and A Perfect Life, share something in common regarding the notion of motherhood. Both of the protagonists in those two titles are trying to escape from the roles of motherhood. They tend to reject the traditional roles of wife and mother in favor of their career and education. They assume that the roles of motherhood just give them restrictions and limit their way to get their freedom. They don't want to be put in the cage only for being passive wives.

In The Word Love, the woman is trying to avoid the traditional roles of motherhood because she doesn't want to be like her mother whom she devotes her life totally for performing the roles of motherhood. 'She' lives in a different world. Can't you see that? She's never traveled more than a hundred miles from

${ }^{29}$ Nigar Alam and Archana Durgesh, "Feminism, Marriage and Role of Women in the Works of Chitra Banerjee Divakaruni," International Journal of English Research 3, no. 6 (November 1, 2017): 4144. the village where she was born; she's never touched a cigarette or alcohol; even though she lives in Calcutta, she's never watched a movie ..." However, it is not easy for her to do so because she gets tremendous pressure from her mother to immediately getting married and get into the traditional roles of motherhood. ${ }^{30}$

Moreover in A Perfect Life, the woman, Meera, first rejects the traditional roles of womanhood because she wants to pursue her career and success. She enjoys her life of being a career woman whom she is very active and bright in her workplace. She often gets stressed when she looks at her friend's life whom she has a baby and becomes very busy in nurturing her baby. In spite of this reality, deep inside her consciousness, Meera cannot deny that she is an Indian woman who rose and grew up with the values of patriarchal culture. The feeling of motherhood upsurges Meera when she suddenly discovers a six-year-old boy one morning in a rose garden. She names the child as Krishna. "Mother love, that tidal wave, swept everything else away Friendship. Romantic fulfillment evens the need for sex". ${ }^{31}$ Meera then ends up with her career and she decides to raise that child. It shows that the doctrine of patriarchy about motherhood in a woman is very strong, that it can take the world of a woman.

Finally, Arranged Marriage book is very rich with the facts and realities of

\footnotetext{
${ }^{30}$ Chitra Banerjee Divakaruni, Arrange Marriage (New York: Anchor Books, 1995), 58-59.

${ }^{31}$ Chitra Banerjee Divakaruni, Arrange Marriage (New York: Anchor Books, 1995), 94-95.
} 
Indian women gender roles. The roles of women as a wife and as a mother are very complex and a woman must be tough to complete it. Roles of women in patriarchal society are already arranged, there are rules and patterns that a woman has to conduct in her life. There will be many consequences a woman has to endure if she cannot carry out her roles well. Patriarchal society will label a woman whom she cannot perform her roles as expected with negative stigma.

\section{Women's Conflict in Chitra Banerjee Divakaruni's Arranged Marriage}

Being women have never been easy in any situation, whether married or unmarried. Those who are married will commonly experience a doubled-burden conflict. They will culturally be justified under husbands' control and are obliged to follow what their husbands want. If they fail to follow this typical rule, they will face some problems and conflicts. The conflicts in domestic circumstances are more likely to happen when the wives are accused to fail to obey the husbands' rules and controls.

In Divakaruni's arrange marriage such conflicts and domestic violence is obviously found in several cases. The dominant cases are because of the cultural belief that wives are husbands'; that women should end up and surrender in an arranged marriage they do not even know who will become their future husband. Their father will arrange a marriage for his daughter when they have already grown up. This internal conflict is saturated within the women's psyche.
“I wanted to cry, but of course I didn't. It would be ungrateful. Father had worked so hard to find this match for me. Besides, wasn't it every woman's destiny, as Mother was always telling me, to leave the known for the unknown? She had done it, and her mother before her. A married women belongs to her husband, her in-laws." ${ }^{32}$

The internal conflict of the main character facing above clearly represents how women in their culture are supposed to give up their destiny into her father and family decision, it is not acceptable to deliver a protest or even betrayal against their father's choices. Their mothers teach them to do so and their mothers' mother and so forth. It is a tradition that has already been upholding strongly. The notion of this sort of culture is somehow problematic for women living in such a cultural background. In one hand, they want to and taught to be obedient to their parents; not to disappointing what their parents have decided for them. On the other hand, women who are tightly bond with this tradition also want to be free to decide what and who to marry. This situation has frequently triggered an internal conflict that the women have to deal with.

The conflict will never end even when they have got married. Now, the power lies on their husband. Commonly, the husband holds the entire control on what his wife should and should not do. A wife has a bare freedom to choose and decide what she wants to do. All they need to do must get permission from their husbands.

32 Chitra Banerjee Divakaruni, Arrange Marriage (New York: Anchor Books, 1995), 19. 
"Your uncle does not like me to go out. $\mathrm{He}$ is telling me it is dangerous". "How can it be dangerous?"

"No harm in it, I am thinking", she finally says. "As long as we are staying close to the house. As long as we are coming back in time to fix a nice dinner for your uncle."33

Wife main duty is to serve husband and to obey all his commands. The data above shows that the main character's aunt was firstly refused when being asked to go out, because her husband doesn't let her go outside without his permission. She is very afraid of betraying her husband's command, however, she finally agreed to go outside only if they can manage to come back home in time before her husband arrived from work. She needs to prepare for her husband's dinner as it is her duty to do so. Serving a husband's daily needs becomes the main duty the wife must satisfy. The notion of husband as breadwinner and the wife as the housekeeper has internalized almost all the wife's thoughts and beliefs in Indian culture. They mostly think that a good wife is their ultimate destiny as women. They seem never to consider their interest and desire. The wife's top priority is to satisfy husbands in any way.

"...had I been wrong all this time, when I refused to let him turn the lights on as we made love when I lay stiff and submissive under his thrust until he was done with it? my mother had explained to me that a good wife's duty was to allow her husband to satisfy

${ }^{33}$ Chitra Banerjee Divakaruni, Arrange Marriage (New York: Anchor Books, 1995), 46. himself no matter how unpleasant she found..." 34

From the story above, it can be clearly seen that husband's satisfaction is the most prominent aspect in marital relationship. Even it is imbued and learned from the very beginning of time when women are ready to get married. The notion of putting husband's satisfaction above all is diffused through the family tradition where Indian women are mostly pertained passing from generation to the next generation. The concept of marital relationship which places husband to have more privilege than the wife is in line with the gender roles perspectives. It is traditional gender role that seems to construct women as the second class after their husbands. ${ }^{35}$ This sort of gender performing has most likely caused an internal conflict of a wife. As a human being, she has personal desire and ambition. She might also want to please herself. Yet, it has not always been that easy to do so as she has to do first is to concentrate on her husband's satisfaction.

The other conflict by the women represented in the story deals with the internal conflict. Such conflict because of the situation that disabled the wife and women to express their desire, most of all they just keep the conflict by themselves. However, they are suffering from insecurities when it deals with physical

\footnotetext{
${ }^{34}$ Chitra Banerjee Divakaruni, Arrange Marriage (New York: Anchor Books, 1995), 243-244.

${ }^{35}$ Elizabeth A. Suter and Paige W. Toller, "Gender Role and Feminism Revisited: A Follow-Up Study," Sex Roles 55, no. 1 (July 1, 2006): 135-46, https://doi.org/10.1007/s11199-006-9065-4.
} 
attributes and judgment. Indian women commonly see beauty from the mainstream perspective which considers fair skin, thin and high body as the standard of beauty. They feel unconfident if they don't meet those criteria. Subsequently, they feel insecure and struggle to get the ideal beauty to maintain the marriage relationship with their husband.

"Still, it had reminded me how, a few evening earlier, Ashok had looked up from a magazine he'd been reading and said, quite out of the blue, "Abha, I wish you'd do something to your hair, go get a perm maybe."

Ashok is Abha's husband who works in a company office. He asked his wife, Abha who works as a freelance writer for a culinary magazine to change her hairstyle. Abhas's looking is somewhat plain just like a typical housewife. She does not really think that physically good looking is needed for her. However, she feels insecure when his husband starts complaining and asking her to make a change in her style. She is afraid of not being good enough for her husband.

"Even under the best of circumstances I am no beauty. If my horoscope hadn't matched Ashok's so perfectly that everyone declared our marriage must have been ordained by the Gods. I doubt that his family would have chosen me". ${ }^{37}$

Abha has been suffering from a lack of confidence; she keeps thinking that it is serendipity to married Ashok. She does

${ }^{36}$ Chitra Banerjee Divakaruni, Arrange Marriage (New York: Anchor Books, 1995), 236.

37 Chitra Banerjee Divakaruni, Arrange Marriage (New York: Anchor Books, 1995), 235. not have the ideal beauty as most men craved for in finding a wife. However, this conflict leads to her insecurities. She is afraid that Ashok will have an affair with her best friend Meena who is perfectly beautiful. Another inner conflict bursts from women as depicted in the story is also experienced by unmarried women. In Indian culture's arranged marriage, it is a sort of dilemma and to women who had not been chosen by any family to propose them. Sometimes, it is simply because of the physical issue that hinders a family from choosing a woman as a wife for their son. Consequently, those who do not have an ideal physical looking feel upset, unconfident, and scared off.

"Are you nervous? Radha asks as she wraps my hair in a soft cotton towel. Her parents also trying to arrange a marriage for her. So far, three families have come to see her, but no one has chosen her because her skin-color is considered too dark. "Isn't it terrible not knowing what's going to happen?."38

Women's body, according to feminist discourse is something complicated. It is associated with gender, identity, and language, the women body is merely an object of men. Even women can hardly control over their own bodies. It has always been designated from men's point of view. Women's body has often become exploitation by media. The visual or print media, in the same way, provides a stereotyped image, an imposition that has to be internalized by 'women' and exhibit their 'beauty' that suits to the

${ }^{38}$ Chitra Banerjee Divakaruni, Arrange Marriage (New York: Anchor Books, 1995), 19. 
popular and dominant perception of the larger community. Sociocultural standards of feminine beauty are presented in almost all forms of popular media, projecting women images that portray what is considered to be the "ideal body." Such standards of beauty are almost completely unattainable for most women. ${ }^{39}$ Therefore, when it is out of society (men's) criteria they might suffer from insecurities and lack of confidence.

Moreover, from the story above it can also be well captured that women have no right to choose what they want to have for their future life. It has been arranged and chosen by their family. Even they surged to give their future for a new life, a new husband that they have never known before. Women's life is like gambling. No one can predict whether it will end up happily or oppositely.

As married women are trapped in the traditional culture which places them as the subordination of their husbands, women are portrayed to be vulnerable to receiving domestic violence. In fact, a Husband, who is supposed to be a good partner and plead his wife, has often been flouting his roles. A wife most likely becomes the victim of domestic violence in marriage life. It is obviously portrayed in the story.

"I noticed something funny about her face. Not the dark circle under her eyes. Those were always there. It was high up on her check, a yellow blotchwith edges turning purple. It

39 Sumita Sarkar, "Media and Women Image: A Feminist Discourse," Journal of Media and Communication Studies 6, no. 3 (March 31, 2014): 48-58, https://doi.org/10.5897/JMCS2014.0384. looked like my knee did after I bumped into chipped mahogany dresser next to our bed last month." ${ }^{40}$

The domestic violence as described above was experienced by the main character's mother who frequently got physical abuse from her abusive husband without any specific reason. The violence occurred in the story shows that the culture where Indian women live still considers that a wife is husband's. Consequently, a wife most likely got improper treatment from her husband. $\mathrm{He}$ stated that also implicit in our culture the idea of spouses and children. This notion also precludes any respect for individual rights. Norms defining people as property operate to permit corporal punishment within one's family, while disallowing violence towards a person outside the family. ${ }^{41}$

"A couple of days later Mother had another mark on her face, even bigger and reddish-blue. It was on the side of her forehead and made her face look lopsided. This time when I asked her about it, she didn't say anything, just turned the other way..." ${ }^{42}$

The power relationship between husband and wife might because of the imbalanced power that results in how the husband considers his wife as his property. The control over women then becomes the cause of domestic violence. The asymmetry of such control contrasted dramatically, it seemed to me, with the

${ }^{40}$ Chitra Banerjee Divakaruni, Arrange Marriage (New York: Anchor Books, 1995), 2.

41 David D. Witt, "A Conflict Theory of Family Violence," Journal of Family Violence 2, no. 4 (December 1, 1987): 291-301, https://doi.org/10.1007/BF00993296.

${ }^{42}$ Divakaruni, Arrange Marriage, 3. 
family violence perspective's predominantly symmetric image of partner violence as a matter of conflict. I hypothesized that there were two qualitatively different forms and/ or patterns of intimate partner violence-one that was part of a general strategy of power and control (intimate terrorism), the other involving violence that was not part of a general pattern of control, probably a product of the escalation of couple conflict into violence (situational couple violence) ${ }^{43}$

The violence against women cannot be stopped easily even by the closest person in the family. The notion that the wife is husband's make the husband's domination getting stronger. The violence keeps continuing even after the main character's mother leaving for her husband. Yet, she decided to come back home to see her husband and live with him no matter what.

"Then, once we had to leave in the middle of the night, too suddenly to take anything with us. Mother stumbled behind me down the lightless passagewe hadn't dared to switch on the lightholding the waded end of her sari to her face, the blood seeping through its white like a dark, crumpled flower. I pulled at her to hurry her along, my shoulder still throbbing when father had flung me against the wall as I tried to stop him". 44

43 Michael P. Johnson, "Conflict and Control: Gender Symmetry and Asymmetry in Domestic Violence," Violence Against Women 12, no. 11 (November 2006): 1003-18, https://doi.org/10.1177/1077801206293328.

44 Chitra Banerjee Divakaruni, Arrange Marriage (New York: Anchor Books, 1995), 15-16.
The story above describes how a wife is very risky to experience domestic violence from her husband. It is a patriarchal belief which becomes the huge repercussion of the violence. Wives can do nothing at all the way. They keep devoting their life to their husbands for the sake of family oneness. The concern for liberal and equality feminists is based on the restriction of public space by war. Betty and Carol Pateman describe the conditioning of men towards aggression and women to submission as the patriarchal contract that the legitimization of violence and war. ${ }^{45}$

\section{Conclusion}

Arranged Marriage book is very rich with the facts and realities of Indian women's gender roles. The roles of women as a wife and as a mother are very complex and a woman must be tough to complete it. Roles of women in a patriarchal society are already arranged, there are rules and patterns that a woman has to conduct in her life. There will be many consequences a woman has to endure if she cannot carry out her roles well.

Patriarchal society will label a woman whom she cannot perform her roles as expected with negative stigma. It caused the women to feel under pressured and overwhelmed by the stigma being attached to them. Consequently, they are most likely to experience unbearable psychological

\footnotetext{
45 Annette Weber, "Feminist Peace and Conflict Theory," in Routledge Encyclopaedia on Peace and Conflict Theory, April 30, 2006, 1-17.
} 
pressures. In addition, domestic outbreaks of violence are also found in several cases. The dominant cases are because of the cultural belief that wives are husbands' that women should end up and surrender in an arranged marriage they do not even know who will become their future husband and how their husband will treat them the rest of their life. Their father will arrange a marriage for his daughter when they have already grown up. This internal conflict is saturated within the women's psyche.

\section{References}

Agarwal, Gunjan, and Gunjan Kapil. "Arranged Marriage: As an Example of Marginalized Relationships." IOSR Journal of Humanities and Social Science 19, no. 10 (2014): 89-93. https://doi.org/10.9790/0837191028993.

Alam, Nigar, and Archana Durgesh. "Feminism, Marriage and Role of Women in the Works of Chitra Banerjee Divakaruni." International Journal of English Research 3, no. 6 (November 1, 2017): 41-44.

Bai, K. Lalitha. "Divakaruni's Arranged Marriage: Quest for a New Beginning." International Journal of Humanities and Social Science Invention 6, no. 11 (November 2017): 83-86.

Beauvoir, Simone de. The Second Sex. Vol. II. London: Jonathan Cape Thirty Bedford Square, 1956.

Damor, Minal J. "Portrayal of Women in Chitra Banerjee Divakaruni's Arranged Marriage." International Journal of Research in All Subjects in Multi Languages 3, no. 6 (June 2015): 23-25.

Divakaruni, Chitra Banerjee. Arrange Marriage. New York: Anchor Books, 1995.
Edgar, Andrew, and Peter Sedgwick. Key Concepts in Cultural Theory. London: Routledge, 1999.

Fernandez, Jasmine. "Realism in Chitra Banerjee Divakaruni's Arranged Marriage." IOSR Journal of Humanities and Social Science 19, no. 3 (2014): 99-101. https://doi.org/10.9790/0837193299101.

Flick, Uwe. Designing Qualitative Research. London: SAGE Publications Ltd, 2007.

Johnson, Michael P. "Conflict and Control: Gender Symmetry and Asymmetry in Domestic Violence." Violence Against Women 12, no. 11 (November 2006): 1003-18. https://doi.org/10.1177/1077801206 293328.

Kumawat SGL, Brajesh, and Payel Dutta Chowdhury. "The Discordant Marital Life of the Diaspora: A Study of Chitra Banerjee Divakaruni's Arranged Marriage and Manju Kapur's The Immigrant." Smart Moves Journal ljellh 3, no. 3 (May 17, 2017): 396-404.

Lewis, Holly. The Politics of Everybody. London: Zedbooks, 2016.

Mukherjee, Jayasree. "Marred by Marriage: The Modern Indian Woman at the Crossroads in Chitra Banerjee Divakaruni's Arranged Marriage." Research Journal of English Language and Literature (RJELAL) 6, no. 1 (2018): 245-50.

Sarkar, Sumita. "Media and Women Image: A Feminist Discourse." Journal of Media and Communication Studies 6 , no. 3 (March 31, 2014): 48-58. https://doi.org/10.5897/JMCS2014.0 384.

Sharma, Ritu. "Woman in Dilemma, A Critical Study of the Female Characters of Chitra Divakaruni's Arranged Marriage." International Journal of English and Literature 9, 
no. 1 (January 1, 2019): 17-24. https://doi.org/10.24247/ijelfeb20193.

Storey, John. Cultural Analysis and Pop Culture. London: Pearson, 2009.

Suter, Elizabeth A., and Paige W. Toller. "Gender Role and Feminism Revisited: A Follow-Up Study." Sex Roles 55, no. 1 (July 1, 2006): 13546. https://doi.org/10.1007/s11199006-9065-4.

Tyson, Lois. Critical Theory Today. New York: Garlang Publishing, 1996.

Usha, A. "Immigrant Experience and SelfDiscovery of Women in the Select Novels of Chitra Banarjee Divakaruni: A Study." International Journal of English Research 3, no. 5 (September 2017): 11-13.

Valiyamattam, Rositta Joseph. "Diaspora and Feminism in Chitra Banerjee Divakaruni's Arranged Marriage." LITERARIA: An International Journal of New Literature Across the World - Special Issue on Indian Diaspora 3, no. 1 (June 2013): 2440.

Weber, Annette. "Feminist Peace and Conflict Theory." In Routledge Encyclopaedia on Peace and Conflict Theory, April 30, 2006.

Witt, David D. "A Conflict Theory of Family Violence." Journal of Family Violence 2, no. 4 (December 1, 1987): 291-301. https://doi.org/10.1007/BF00993296. 